\title{
Garlic (Allium sativum) As Natural Larvacides For Aedes Aegypti Larvae
}

\author{
Siti Rahmah ${ }^{1}$, Agus Erwin Ashari ${ }^{2}$, Endang Suryadi ${ }^{3}$, Miftah Chairani $^{4}$ \\ \{ sitirahmah.akhsan@gmail.com ${ }^{1}$, agus.rpjmn@gmail.com², \\ endangsuryadisaimang@gmail.com ${ }^{3}$, miftahchairani@gmail.com ${ }^{4}$ \} \\ Midwifery Department, Faculty of Medicine, Universitas Sebelas Maret, Surakarta, Central Java, \\ Indonesia
}

\begin{abstract}
Application larvicides synthetic in the long term could be expected to cause resistance, so it required an effort of larvicides alternative, one of them is with natural larvicides derived from plants to toxic insects but harmless to humans and the environment. Garlic contains allicin, and diallyl sulfide has bactericidal and flavonoid that act as a respiratory inhibitor to insects. The objective is to determine the effectiveness of garlic against Aedes aegypti larvae mortality. We did experimental studies with Aedes aegypti larvae as research subject which is tested with garlic solution with concentration and a certain amount of time. The larvaes were divided into 6 groups: concentrations of $10 \%, 15 \%, 20 \%, 25 \%, 30 \%$, and control (without treatment). Each group contains 20 larvaes observed every 3 hours, 6 hours, 9 hours, and 12 hours with 3 repetitions. Garlic solution is effective if Aedes aegypti larvae death more than 50\%. The data were analyzed based on guidelines for laboratory and field testing of mosquito larvicides by WHO. At concentration of $10 \%$ larvae mortality by $30 \%$, concentration $15 \%$ larvae mortality $45 \%$, concentration $20 \%$ larvae mortality $75 \%$, concentration $25 \%$ larvae mortality $85 \%$, and concentration $30 \%$ larvae mortality of $90 \%$ while in control group there is no dead larvae. Effective garlic solution to kills larvae at concentrations of $20 \%, 25 \%$, and $30 \%$. We recommended using garlic solution with high concentrations to killing larvae at containers.
\end{abstract}

Keywords: Garlic, Aedes aegypti, Larvae, Larvicides.

\section{Introduction}

Aedes aegypti is a mosquito that may act as a vector for Dengue Hemorrhagic Fever (DHF) [1]. Mosquitoes will swallow the dengue virus if they suck the blood of DHF patients [2]. The virus will enter the intestine of mosquitoes and then replicate in the hemocoelum. Then the virus will go into the mosquito saliva gland and is ready to be transmitted [3].

Dengue and DHF have been endemic in more than 100 countries in the WHO region in Africa, America, Eastern Mediterranean, Southeast Asia, and the Western Pacific. The Southeast Asian and Western Pacific regions are the most seriously affected [4]. In 2016 there were a total of 204,171 dengue cases with 1,598 deaths. The number of dengue cases in 2016 increased compared to the number of cases in 2015 of 129,650 cases [5]. Whereas in 2017, there were $84.44 \%$ of districts/cities in Indonesia that is still infected with DHF, including all districts in West Sulawesi Province [1]. 
The use of insecticides is one of the methods used to eradicate mosquitoes. Synthetic chemical insecticides that are used in the long term may develop resistance insects, cause disease, and can even cause poisoning in case of excessive use. Prevention act to prevent this from happening is to use the natural ingredients that are found around us as natural insecticides [6].

One of the choices for controlling DHF vector naturally is garlic plants. The larvicidal activity of garlic is thought to be played by Allicin, and Diallyl disulfide has bactericidal and bacteriostatic properties. Allicin works by interfering with the synthesis of parasite cell membranes so the parasites cannot grow further. Allicin is also toxic to the parasite and bacterial cells [7]. The oil content in the garlic solution may change the surface tension of the water so that the larvae have difficulty taking oxygen from the water surface. This is thought to cause the larvae not to get enough oxygen to grow, leading to larval death [8].

The other compound of garlic that is thought to play a role in the larval death is flavonoids. This substance works as a respiratory inhibitor. Flavonoids are thought to interfere with energy metabolism in the mitochondria by inhibiting the electron transport system. The difficulty in the electron transport system will prevent ATP production and cause a decrease in oxygen consumption by mitochondria [9]. The compounds found in garlic include Allicin and Sulfur Ammonia acid Allin. This sulfuric ammonia acid Alin is converted to Pyruvic Acid, Ammonia, and Allicin Anti Microbes by Allicin Lyase Enzyme. After that, Allicin changes to Diallyl disulfide. Allicin and Diallyl Sulphide compounds have many benefits and are efficacious as drugs. Allicin and its derivatives also have a larvicidal effect [10].

The objective of this study was to determine the effectiveness of garlic (Allium sativum) solution in killing Aedes aegypti larvae with 10\%, 15\%, 20\%, 25\%, and 30\% concentrations.

\section{Materials and Method}

This is experimental research with research subjects were Aedes aegypti larvae which were tested with garlic solution in concentrations of $10 \%, 15 \%, 20 \%, 25 \%$, and $30 \%$ accompanied by a control group that was not given the addition of garlic solution, with each group consists of 20 larvae. The Aedes aegypti larvae groups were observed every 3 hours within 12 hours of contact with the garlic solution. The observation was repeated in 3 attempts. Garlic solution is stated to be effective if the death of Aedes aegypti larvae is more than $50 \%$. Research data were analyzed based on Guidelines for Laboratory and Field Testing on Larvicide Mosquitoes published by WHO [11].

The making of garlic solution used fresh simplicia squeeze method, which is the method used for fresh simplicia in the form of tubers, rhizomes, leaves, and fruit. The process begins with the destruction of simplicia then squeezed and filtered. Sufficient water may be added to the squeeze process if needed [12]. The garlic solution effective when the solution can kill more than $50 \%$ Aedes aegypti larvae.

\section{Results}

Mosquito larvae were divided into 6 treatment groups, namely $0 \%$ as control and $10 \%$, $15 \%, 20 \%, 25 \%$, and $30 \%$ concentration of garlic solution. 
Table 1. Larval Death in relation with by Garlic Solutions Concentration

\begin{tabular}{ccccccccc}
\hline \multirow{2}{*}{ Concentration } & \multicolumn{2}{c}{3 hours } & \multicolumn{2}{c}{6 hours } & \multicolumn{2}{c}{9 hours } & \multicolumn{2}{c}{12 hours } \\
\cline { 2 - 9 } & $\begin{array}{c}\text { Average } \\
\text { Larvae } \\
\text { Survival }\end{array}$ & $\%$ & $\begin{array}{c}\text { Average } \\
\text { Larvae } \\
\text { Survival }\end{array}$ & $\%$ & $\begin{array}{c}\text { Average } \\
\text { Larvae } \\
\text { Survival }\end{array}$ & $\%$ & $\begin{array}{c}\text { Average } \\
\text { Larvae } \\
\text { Survival }\end{array}$ & $\%$ \\
\hline $0 \%$ & 20 & 0 & 20 & 0 & 20 & 0 & 20 & 0 \\
$10 \%$ & 20 & 0 & 19 & 5 & 16 & 20 & 14 & 30 \\
$15 \%$ & 20 & 0 & 18 & 10 & 15 & 25 & 11 & 45 \\
$20 \%$ & 19 & 5 & 14 & 30 & 9 & 55 & 5 & 75 \\
$25 \%$ & 17 & 15 & 8 & 60 & 5 & 75 & 3 & 85 \\
$30 \%$ & 16 & 20 & 5 & 75 & 3 & 85 & 2 & 90 \\
\hline
\end{tabular}

Solution with $0 \%$ garlic concentration as a control showed $0 \%$ mortality of larvae. This proves that the water solution without additional garlic solution does not affect the larvae.

Solution with garlic concentration of $10 \%$ and $15 \%$ is not effective in killing Aedes aegypti larvae in 12 hours. Solution with garlic concentration of $20 \%$ began to effectively kill Aedes aegypti larvae at 9 hours of observation and still killed more Aedes aegypti larvae until 12 hours observation. A solution with garlic concentration of $25 \%$ and $30 \%$ began to effectively kill Aedes aegypti larvae at 6 hours of observation and kill more larvae until observation for 12 hours.

\section{Discussion}

The results in table 1 show that the greater the concentration given to the larvae, the greater the number of larval deaths. This may lead us to believe that there is a relationship that is directly proportional between the amount of garlic concentration and the number of deaths of Aedes aegypti larvae. The more concentrated garlic in the solution indicates more active substance contained in the solution. This causes the higher potency of the solution to kill Aedes agypti larvae.

This is in line with the Sumampouw study in Manado [13] and Sulistyonongsih's research [14] which showed that the garlic solution had an effect on Aedes spp larvae and an increase in the concentration of garlic solution consistent with the number of deade Aedes spp larvae.

The active substances contained in the garlic solution, which play a role in larvicidal mechanisms are allicin and flavonoids. Allicin will interfere with the synthesis of parasitic cell membranes so that the parasite cannot grow further [15]. Also, allicin is also toxic to the parasite and bacterial cells. Allicin will damage sulfhydryl $(\mathrm{SH})$, which is present in the protein while the membrane structure of the larval cell consists of protein with Sulfhydryl. Allicin will damage the larval cell membrane, which will cause lysis. Based on this mechanism, Allicin can inhibit the development of 3rd instar larvae into 4th instar larvae or 4th instar larvae will not turn into pupae and will eventually die because the cell membrane has been damaged [13]. 
At the same time, flavonoids work as respiratory inhibitors. Flavonoids are thought to interfere with the energy metabolism in mitochondria by inhibiting the electron transport system so that it inhibits ATP production and causes a decrease in oxygen consumption by mitochondria [6]. When flavonoids are absorbed and entered into the body cavity excessively, vasoconstriction in the body cavity becomes damaged, and hemolymph cannot be perfectly distributed. Damage to the respiratory and body cavities ultimately leads to death [16].

Utilization of garlic solution to control Aedes aegypti larvae is one way to reduce insecticide use, which has proven to hurt the environment. The active substances contained in garlic are allicin, flavonoids, and their oil content can make the Aedes aegypti larvae slowly die because the active substance can directly affect the physical and environmental conditions of the larvae.

\section{Conclusion}

Based on this research, we found that the higher concentration of garlic solution such as $20 \%, 25$, and $30 \%$ are Effective garlic solution to kills larvae. Garlic is a plant that is used as a kitchen spice so it is always provided at home, so it is very easy to get. Also, garlic is also environmentally friendly, safe for human health, and has been proven to be used as a phytoinsecticide. However, this has not been well socialized to the societies so it is recommended for health workers to promote traditional plants that can be used as alternatives to eliminate Aedes aegypti larvae, such as garlic solution.

Acknowledgments. We would like to say thank you to college students, instructors, and laboratories of Poltekkes Kemenkes Mamuju who helped this research.

\section{References}

[1] Kementerian Kesehatan Republik Indonesia.: Profil Kesehatan Indonesia 2017 Jakarta. (2018)

[2] Palgunadi B U and Rahayu A.: Aedes aegypti Sebagai Vektor Penyakit Demam Berdarah Dengue J. FK. Universitas Wiajya Kusuma Surabaya.Vol.1.pp.1-5 (2011)

[3] Pan American Health Organization. Tool For The Diagnosis and Care of Patientes With Suspected Arboviral Diseases (Washington: PAHO Publication). Pp. 62-70(2017)

[4] World Health Organization.: Prevention and Control of Dengue and Dengue Haemorrhagic Fever (India: WHO Regional Office for South-East Asia). Pp.50-59(2011)

[5] Kementerian Kesehatan Republik Indonesia.: Profil Kesehatan Indonesia Tahun 2016 Jakarta Kementerian Kesehatan Republik Indonesia. Pp.7-9(2017)

[6] Sasmilati U, Pratiwi A D and Ahmad LO.: Efektifitas Larutan Bawang Putih (Allium Sativum Linn) Sebagai Larvasida Terhadap Larva Aedes aegyti di Kota Kendari Tahun 2016 . Vol. 2, pp. 1-7. (2017)

[7] WE S and E S.: Influence of Garlic (Allium sativum L) Leaf Extracts as Reppelent Againt Aedes aegypti J. Universitas Lampung. pp. 195-202. (2014)

[8] Adeleke M A and Onakhinor S.: Ovicidal and Larvicidal Effects of Some Organic Pollutants on Aedes Aegypti Annals of West University of Timisoara ser Biology. Vol. 20, pp. 167-170. (2017)

[9] Darmadi.: Uji Daya Hambat Ekstrak Bawang Putih (Allium sativum) Terhadap Larva Anopheles sp Vol.73 pp.16-23. (2014)

[10] Hanani S J, Hiola R P and Amalia L. Uji Efektifitas Larutan Bawang Putih Sebagai Insektisida 
Nabati Untuk Membunuh Larva Nyamuk Aedes aegypti. J. Kesmas. Universitas Gorontalo. pp. 7 18. (2013)

[11] World Health Organization.: Guidelines For Laboratory and Filed Testing of Mosquito Larvacides (Geneva: WHO). Pp. 7-10. (2005)

[12] Sulistyani N.: Modul 006 Pengembangan Sediaan Obat Tradidional (Jakarta: Ristekdikti).pp.25-40 (2018)

[13] Sumampouw S P M, Pijoh V D and Wahongan G J P. Pengaruh Larutan Bawang Putih (Allium sativum) Pada Larva Aedes spp di Kecamatan Malalayang Kota Manado J. e. Vol. 2, pp 1-6. (2014)

[14] Sulistyonongsih D, Santosa B and Sumanto D. Efektifitas Larutan Bawang Putih Dalam Membunuh Larva Aedes aegypti J. Kesehatan. Vol. 2, pp. 38-44. (2009)

[15] Singh B, Singh P R and Mohanty M K. Toxicity of a Plant Based Mosquito Repellent/Killer. Interdisciplinary Toxicology. Vol.5, pp. 184-191. (2012)

[16] Febri Rahma. Efektifitas Bawang Putih (Allium sativum) Dalam Membunuh Larva Nyamuk Universitas Teuku Umar. pp. 9-10. (2014) 